\title{
Originalartikel
}

\section{The included outlaw}

\section{A study of the seclusion in Amalie Skram's Professor Hieronimus}

\section{Ingri Løkholm Ramberg}

Health, Art, Society (HAS) The Arctic University of Norway (UiT)

ingri.l.ramberg@uit.no

Ramberg, Ingri L. (2019) The included outlaw: A study of the seclusion in Amalie Skram's Professor Hieronimus . Tidsskrift for Forskning i Sygdom og Samfund, nr. 31, 73-88.

This article presents an analysis of Amalie Skram's 1895 novel Professor Hieronimus, with an emphasis on the seclusion aspect of this patient narrative. In the article, I give a close reading of the novel where I make use of insights from theorists from different disciplines, such as Shoshana Felman, Erving Goffman and Giorgio Agamben. The intent of the analysis, is to show how Skram manages to expose the rigid social categories that characterize the total institution in which the novel's protagonist, Else Kant, claims to be wrongfully lodged. Through a critical assessment of the institutional hierarchy, both social and medical, Amalie Skram makes her novel well-suited for the type of interdisciplinary readings that in the last couples of decades have expanded and become more accessible, thanks in part to the emergence of the field of literature and medicine. This development grants us the opportunity to revisit the works of the Scandinavian literary canon with a fresh theoretical perspective, where fiction bears the potential to articulate aspects of the patient experience that has yet to be encapsulated by theory. This article shows how this phenomenon includes studies that are not limited to this interdisciplinary field alone, meaning that a complex patient narrative such as Skram's Professor Hieronimus is accessible to a broader theoretical material as well. 


\section{The included outlaw: A study of the seclusion in Amalie Skram's Professor Hieronimus}

If we were to establish a Scandinavian canon of illness literature, Amalie Skram's novel Professor Hieronimus from 1895 would be a cornerstone. Yet, as its only mentioned diagnosis, madness, is debated and disputed in the novel and the protagonist keeps insisting that she is wrongfully hospitalized, many of the categories and descriptions found in the theoretical literature regarding illness stories and patient narratives are challenged. In this article, I will explore how Skram's novel articulates vital aspects of the patient experience that will be addressed by theorists and philosophers at significantly later points in history, both within and outside the interdisciplinary field of literature and medicine. The intent of the study is to show, how Skram's novel manages to expose the hollowness of the strict social and medical categories characterizing the institution portrayed in her novel.

Professor Hieronimus is the first part of a duology that continues with På St. Jørgen, published the same year as its precursor. Both novels describe the experience of being kept as a patient against one's will, where communication and language fall short within the structures of an institutionalized health system. Professor Hieronimus, which will be analyzed in this article, aptly exemplifies the significance of the seclusion. This is often mentioned as a vital part of the patient experience without being subject to further elaboration, and it is in part this, I will try to remedy in my reading of Skram's novel. In addition, I will include insights on isolation as a phenomenon of thinkers from outside the field of literature and medicine. Overall, this article gives an examination of seclusion and isolation from different theoretical angles, as well as a close reading of the animalistic imagery in the novel. In this, I will discuss how Skram exposes the total institution's hierarchy and categories in a way that makes her novel accessible to analytical approaches across disciplines.

\section{Professor Hieronimus}

Professor Hieronimus' protagonist, Else Kant, is in a state of crisis amongst other things due to the pressure of functioning as a mother, a wife and an artist simultaneously. She is sleep-deprived, unable to work, and experiences hallucinations and suicidal thoughts. She finally agrees to commit herself under the care of the well-known Professor Hieronimus whose dissertation she has read with interest. 
However, as soon as she has crossed the threshold of the asylum she is denied access to her belongings and she is prohibited from contacting her family or anyone else outside the hospital. The meeting with the professor is deeply disappointing to her and she experiences the stay as imprisonment, where she is isolated, stripped of her rights and dignity, and accused of being insane. At the end of the novel, she is transferred to a so-called insane asylum, and as she leaves, she promises the professor that the minute she is out of the institution he will be held accountable for his mistreatment of her and her fellow patients.

The novel caused quite a stir at the time of its publication, in part due to the fact that it was read as an autobiographical account of the some-two months that Skram herself had spent in hospitalization in 1894. First in the municipal hospital in Copenhagen, and later in the insane asylum Sct. Hans. In the debate following the publication, other (female) patients shared their accounts of being under the care of Knud Pontoppidan, who was widely understood to be the biographical model for Professor Hieronimus. After the debacle, he published a form of apologia, 6te Afdelings Jammersminde (1897), and eventually resigned from his position. ${ }^{1}$

Seclusion is an important keyword in Skram's novel, which connects it to the theoretical literature concerning (alleged) madness, illness, and hospitalization where this experience is often accentuated. More often than not, scholars will emphasize that being hospitalized, not only means a break from usual routines or company, but also, that entering an institution includes isolation so profound that it changes the patient's world, often by her entering a different one. Skram is a pioneer in addressing such seclusion in literary form, and in Denmark alone, we can see clear literary descendants both in writers from Skram's time and at later points in literary history. Helga Johansen, for example, wrote the novel Hinsides in 1900 and the text possesses clear parallels to Professor Hieronimus (it was published under the pseudonym Hanna Jöel). A later example is the more famous Tove Ditlevsen's novel Ansigterne from 1968. Both address the medical institution as a secluded otherworld and they use this other world to explore the connection between "madness" and artistic creation, both writers were even hospitalized in the same institutions as Skram.

To mention a few examples of the emphasis on seclusion in theory related to literature and medicine: In Litterära besvär, Katarina Bernhardsson refers to a patient describing his hospital room as a world within a world, or rather a world outside the ordinary world (Bernhardsson, 2010: 11). Anne Hunsaker Hawkins' influential Reconstructing illness, describes how "the individual - now a patient - crosses a threshold into a strange otherworld of rituals and ordeals, an unknown territory [...]. 
[W]hether they want to or not, the sick become denizens of a strange land" (Hawkins, 1999: 78). Hilde Bondevik and Knut Stene-Johansen describe, how the isolation connected to the hospitalization in literature provides us with the opportunity to view the medical institution as a laboratory for human experience (Bondevik and Stene-Johansen, 2011: 137-139). In Madness and civilization (L'histoire de la folie à l'âge classique), Michel Foucault famously outlines how we have condemned different types of insanity to exist outside society where the stultifera navis, the 'ship of fools' is replaced by a hospital that locks madness in (or out), which he labels 'the great confinement' (Foucault, 2008: 30-32). Equally famous in regards to illness literature is Susan Sontag's classic Illness as a metaphor, where illness is understood as a kingdom of its own and the asylum as a world of its own: "Once put away, the patient enters a duplicate world with special rules" (Sontag, 1978: 36).

\section{Madness as 'outside culture'}

In Writing and madness, Shoshana Felman, building on Foucault, states that our society builds walls around mental institutions "to keep apart the inside and the outside of a culture, to separate between reason and unreason and to keep apart the other against whose apartness society asserts its sameness and redefines itself as sane" (Felman, 2003: 5). She also writes, that "[m]adness usually occupies a position of exclusion; it is the outside of a culture" (Felman, 2003: 13). In her book, Felman describes madness as "the most subversive of all cultural questions", and states that the phenomenon causes different theoretical disciplines to converge (Felman, 2003: 12). Felman's examples of the disciplines, whose boundaries are subverted by the question of madness include sociology and philosophy (and history, psychology, literature and psychiatry). This statement which will be put to use in this article, as the patient experience described in Professor Hieronimus will be analyzed with help from respectively a philosopher and a sociologist, namely Agamben and Goffman.

Felman asserts, that madness only represents the outside of a culture, and thus a position of exclusion, as long as it is not a commonplace. When madness becomes inflated or overly accessible, the phenomenon starts to represent, according to her, "a position of inclusion and becomes the inside of a culture" (Felman, 2003: 13). The perceived madness in Professor Hieronimus becomes for us the inside of a culture for several reasons. For one, because the question of madness within the walls of the hospital is continuously debated and changes throughout the novel: Kant's initial reluctance to share even the same floor as 'madwomen' develops into 
a form of solidarity. As she actually feels somewhat better and becomes more mentally stable after a time spent in the institution, the question of her insanity from the doctor's point of view is less up for debate than before and his belief that she is insane becomes stronger. In addition to this, as Kant exposes her doctor as no less abnormal or irrational than herself, she makes the 'madness' category somewhat fluent and thus turns what is initially an outside culture into an inside one.

\section{Asylums and Homo sacer}

Both Giorgio Agamben's Homo sacer and Erving Goffman's Asylums examines forms of seclusion with vastly different approaches. Agamben treats his study as a sort of macro theory on modern society and it is especially the chapter titled "The ban and the wolf" that can provide us with increased comprehension of the isolation in the novel. His idea of 'bare life' will also be briefly made use of, as it directly addresses the experience of being 'banned' from a political or social form of life, which is an effective (if drastic) description of the patient experience formulated in Skram's novel. 'Bare life' as understood by Agamben, means that the banned citizen operates "in an inclusive exclusion as the referent of the sovereign decision" (Agamben, 1995: 85). Especially, the image of animality in relation to madness, an ancient combination, becomes apparent in Skram's novel when read in light of Agamben's discussion of the werewolf as an image of the citizen being both banned and included at the same time. He does not, then, focus on the patient experience, but rather on the seclusion from society understood as a ban. He shows how a citizen forced out of a social or political sphere remains deeply connected to the powers that have put her on the outside.

Goffman's work, on the other hand, is explicitly dedicated to the experience of belonging to an institution and provides us with a thorough description of the concept of social control within a secluded medical institution. His work, therefore, becomes a fitting example of how predecessors to theory can be found in fiction that connotes Felman's assertion, that literature has played an important role in developing our culture's receptiveness of 'madness' (Felman, 2003: 14-15). Goffman adds to the common depiction of the medical institution as a separate world, as he describes it as "something of a world for [its members]" (Goffman, 2009: 4.). However, unlike many others making use of this figure of speech when describing the patient experience, Goffman elaborates on the subject. These two theorists, Agamben and Goffman, will ideally complement each other's insights with 
their exceedingly different approaches to different types of seclusion, which in this analysis will supplement a few analyses of Skram's novel and mentions of the isolation aspect of the patient experience as found in the field of literature and medicine.

\title{
The hospital as a total institution
}

In Asylums. Essays on the social situation of mental patients and other inmates, Goffman explores institutions characterized by exactly the type of seclusion described in Skram's novel. The total institution is a key term in Goffman's study of the treatment of mental patients and other inmates in Western history. The kind of institutions that qualify as total are described as such:

\begin{abstract}
"Their encompassing or total character is symbolized by the barrier to social intercourse with the outside and to departure that is often built right into the physical plant, such as locked doors, high walls, barbed wire, cliffs, water, forests or moors" (Goffman, 2009: 4).
\end{abstract}

Goffman goes on to describe the different types of institutions that fit this characterization, which he divides into separate groups. ${ }^{2}$ The hospital where Kant becomes a patient can be said to belong to a group described as "places established to care for persons felt to be both incapable of looking after themselves and a threat to the community". Goffman mentions mental hospitals as an example of such an institution (Goffman, 2009: 4). The degree of seclusion and isolation that Kant faces with her entrance to the hospital surprises her but it soon becomes clear that she is deemed both incapable of looking after herself and a threat to the social order, thus, a degree of isolation is thought to be a fitting treatment for her, despite her protests

Goffman's insights derive from a study of a large patient institution in the US in the 1950s (Goffman, 2009: vii) and can for that reason not without hesitation be used to gain a fully nuanced understanding of the hospitalization and patient experience portrayed in Skram's novel, which is set in a different country in a different era. Yet, his descriptions of the total institution comply with Kant's accounts: The social control, the communication difficulties between patients and staffers (where the latter are often understood as condescending and highhanded) and the patient's experience of lost integrity. Most of the specific examples mentioned in Goffman's analysis (the denied access to one's belongings, the opening of the 
patient's mail, the lost ability to control routines, diet and sleep patterns) all occur in Skram's patient narrative.

Petter Aaslestad reminds us in Pasienten som tekst, with a nod to Foucault, that how we view madness, mental illness and different forms of treatment of such cases, changes through the eras (Aaslestad, 2007: 21). When reading Skram in light of the theory that explores seclusion, this must be considered; In arguing that we should (re-)read Skram's novel today, it is not from the assumption that being hospitalized today is interchangeable with the patient experience as described in a work of fiction from the 1890s. Skram nonetheless anticipates aspects of the patient experience that would, later on, be addressed and expressed in the theoretical literature. Thus, she provides us with a literary-aesthetic knowledge that can later be supplied by an epistemic one even though the context of the mental hospital is different in Skram's context than in Goffman's.

More often than not, works that set out to provide an overview of the psychiatric history of Denmark mention the case of Amalie Skram, how the novels processing her hospitalization caused other (previous) patients to contribute their stories as well, and how this eventually led to Knud Pontoppidan resigning from his position (see for example Kragh, 2008: 148, or Nielsen, 2018: 22). Kragh stresses, that at the time of Skram's hospitalization there were no truly effective treatment methods in Danish psychiatry for 'madness' (Kragh, 2008: 148-149), and Petter Aaslestad points out that there were no 'insanity laws' in Denmark at the time (Aaslestad: 2009). There were, however, extensive discussions regarding the issue and this could be part of the reason why Skram's two novels made such a debacle at the time of their publishing, paired with the fact that Knud Pontoppidan was a well-known and reputable public figure.

Thus, Skram writes herself into not only the Scandinavian history of literature but of medicine as well. Readers have for good reasons assumed that the historical model for the hospital portrayed in Professor Hieronimus is the municipal hospital in Copenhagen, where Skram was briefly hospitalized in 1894, before being transferred against her will to Sct. Hans insane asylum. We, therefore, find pieces of Danish medical and psychiatric history in the novel. For example, Jens-Emil Nielsen discusses, how several institutions sat out to copy the structure of the Copenhagen institution (Nielsen, 2018: 12): There were about twenty cells for delirious or 'severely insane' patients, but under Knud Pontoppidan's leadership the hospital developed into an institution where patients could be hospitalized before they potentially were transferred to Sct. Hans (Nielsen, 2018: 12), thus becoming outlaws on a larger scale than before. 
In an otherwise insightful reading of Skram's asylum novels from 1992, Sammenbrudd og gjennombrudd. Amalie Skrams romaner om ekteskap og sinnssykdom, Irene Engelstad writes, that it is rare for a psychiatric patient to feel the need to share the experiences afterwards. She suggests, that when Skram does this anyway it can be related to masochistic destructive tendencies which researchers like Pil Dahlerup have argued is widespread especially amongst female naturalists (Engelstad, 1992: 175-176, Dahlerup, 1975: 32-33). Rather than seeing Skram's ability to transform her experiences into a groundbreaking observation of the rigid social categories of the medical institution as an expression of self-destructive tendencies typical of female artists from her era, new theoretical developments enable us to gain a fuller understanding of Skram as a pioneer in the patient narrative tradition. This is not made less pertinent, by the fact that today a great many former patients feel a need to share their experience of hospitalization after they have left the institutions. Regardless, Skram's protagonist becomes both an observer of the hierarchy as well as somewhat of an outlaw in the total institution. This calls for a closer examination of what this last part entails.

\section{The patient as homo sacer}

Agamben's study of the banned citizen can provide us with a better understanding of the patient as an outlaw, a supplement to our understanding of her as a participant in a total institution. Kant arrives at the hospital with the perception that she has rights as a patient but gradually realizes that this is not the case. "The law is on the side of the normal", as Virginia Woolf states in her essay "On being ill" (Woolf, 2002: 23). Upon leaving the institution at the end of the novel, Kant makes a final attempt of negotiation with a doctor regarding her state as an outlaw:

"- Does a man have the legal right to lock up his wife in an insane asylum against her will, as soon as he and a doctor declares her insane?

- Yes. And vice versa.

- Then abuse can easily occur, said Else.

- Yes, and that seems to happen quite a bit, too, was the resident doctor's re sponse.

- And I have no rights? I'm not allowed to speak to an attorney or a friend?

- No, not when You're here. And the chief physician at "St. Jørgen" can keep You there for years if he wants to - there came a smile of triumph in the 
resident doctor's eyes, as if of enjoyment over the power possessed by doctors." (Skram, 1978: 164-165) ${ }^{3}$

The forced isolation and the loss of her rights as a patient makes Agamben's study a fitting supplement for a better understanding of the seclusion in the case of Kant. It revolves around the homo sacer, a figure from Roman law that can legally be killed, but not sacrificed, and Agamben argues that this figure communicates relevant aspects to understand the sovereign power over individuals in our modern society. The banned citizen lives outside the law because he has no protection from it. But because he is banned, he is still fundamentally attached to the law. The homo sacer is, in other words, included "solely in the form of its exclusion" (Agamben, 1995: 8) which is a trait the figure can be said to share with the involuntary hospitalized.

Agamben discusses the modern homo sacer figure in its most extreme form, as seen in prison and concentration camps, and his examples are no doubt more 'severe' than how we today would consider a well-functioning hospital in Denmark in the 1890s. However, the hospital is referred to by the patients of the novel as a prison. The parallel between the hospital and the prison in Professor Hieronimus is first made in the form of a simile as Kant expresses her reluctance to enter the institution as her husband drops her off: “- I don't want to go in. It's locked, as if it were a prison" (Skram, 1978: 23). Later in the novel, the similarity has evolved into a metaphor:

"she recollected with horror the first evening, when she relatively audacious had come here without knowing that she for an indefinite period was entering a prison and were to be treated as a culprit, to whom not even those closest to her would gain access" (Skram, 1978: 74).

Finally, upon leaving the institution and on her way to the insane asylum the very last sentence in the novel reads: "And finally she was heading to her new prison" (Skram, 1978: 166). Goffman specifies that "what is prison-like about prisons is found in institutions whose members have broken no laws" (Goffman, 2009: xxi), a statement which rings true in Kant's descriptions of the asylum.

In Homo sacer, Agamben describes a dividing of life into two different parts initially done by the Greeks: 'Life' could either mean bios or zoé, where the former points to social life integrated in a society (also referred to as 'political life'), and the latter is 'the bare life', which is the life excluded from society, the life that we 
share with animals. Bios, then, is a qualified form of life, while zoé is the natural, reproductive life (Agamben, 1995: 109). The homo sacer figure is someone who has been reduced from the political/social to the bare life and is, therefore, excluded from society whilst remaining connected to it. Kant is a seemingly successful artist and her experience of hospitalization can be described as a reduction from a more social/political sphere to one closer to the animal sphere. This reminds us of Felman's divide between the inside and the outside of a culture, and it brings us to the animalistic descriptions in the novel.

\section{The social animality of the institution}

Kant is at first deeply uncomfortable with being placed in the same sphere as patients she considers to be far 'madder' than herself. The delirious patients' persistent screams in the night are continuously described as cries as from wild animals and serve in the beginning as proof for Kant that she does not belong in such surroundings. At a later point in the novel, when she to a larger degree has accepted her temporary fate as a patient, belonging to a wing of the institution where her voice is not heard and her opinions are not considered, she has the following reflection: "Yes, yes, yes, she was taken care of and looked after like a strange animal" (Skram, 1978: 161). The numerous juxtapositions of the patients and animals serve as a possible argument that they are reduced to a form of bare life under Professor Hieronimus' care. The fact that Kant sees them this way as well connects her to the oppressive rulers and complicates the medical hierarchy.

In the beginning, Kant's main issue is that the delirious patients that live one floor beneath her keep her up at night with their animal-like screams: "Then began the horrors from the previous night. The same [...] inhuman roars, pervading bawls and swears from the delirists downstairs" (Skram, 1978: 44). At a slightly later point in the novel, her fellow patients are more explicitly made animal: "Suddenly she heard a bowl that had nothing human to it [...]. It was like a howling from mad dogs, like bellows from bulls, like cockcrow, like owl's hoots" (Skram, 1978: 90). The screams also remind Kant of lions, tigers and wolves (Skram, 1978: 93).

The threshold between the human and the animal life is particularly fitting in the case of homo sacer in the section of the study titled "The ban and the wolf", where Agamben explicitly makes use of animal imagery: The figure of the werewolf is used to describe the outlaw in Germanic and Scandinavian(!) societies: "a monstrous hybrid of human and animal, divided between the forest and the city - the werewolf 
- is [...] in its origin the figure of the man who has been banned from the city" (Agamben, 1995: 105). The outlaw is not seen completely as an animal but exists in a threshold state between the two spheres, in a "zone of indistinction between the human and the animal" (1995: 106). The outlaw is, thus, both excluded from and included in society at the same time: "The life of the bandit is the life of the [...] werewolf, who is precisely neither man nor beast, and who dwells paradoxically within both while belonging to neither" (Agamben, 1995: 105).

As Kant's initial attempts to reason with the nurses and the doctors fail, and she is not permitted to leave the institution, communicate with anyone or gain access to her things her view of the asylum's animality gradually changes. The sounds from the other patients start to become bearable and then something actually soothing for Kant as her hospitalization progresses and she to an increasing degree identifies with the patients of the asylum: "Then sounded cries as from wild animals. Else stiffened with fear for a moment, but then she knew it was the delirists downstairs, and something like relief ran through her. Thank God for the delirists!" (Skram, 1978: 110). As shown by amongst others Petter Aaslestad (2009) and Christine Hamm (2000: 81-82), Kant becomes part of the asylum's structure and hierarchy, and to a certain degree accepts its laws, despite always insisting that she does not belong there, and one of the indicators of this development is that she starts to accept and even identify with her fellow patients' animalistic ways of protest.

A final instance of animals as an image that connects Kant to the confined world of the asylum, is the hallucinations she experiences at the very beginning of the novel before she agrees to her hospitalization. After several sleepless nights and a severe cough, she sees a herd of horses entering her bedroom door and it becomes clear that this is a recurring vision for her. The horses are beautiful but ominous, lifeless and without eyes, and they disappear the moment her husband, Knut, enters the room. Her profound amazement over the fact that he cannot see the horses makes him plead for his wife to seek medical help. A previous analysis of this motif, made by Engelstad in 1992, has focused on the fact that the horses lack eyes. Engelstad reads this in light of Else's other visions and hallucinations where this lack is a recurring trait and she connects this to Kant's artistic crisis, as she fears that she has lost her artistic vision (Engelstad, 1992: 194-195). In our context, however, it seems more pertinent to view the herd in light of the other animalistic imagery in the novel. The hallucination could initially easily serve as a foreshadowing of Kant's transition to an animal-like sphere. Conspicuously enough, after she has actually spent some time in the confined world of Hieronimus' asylum, the hallucination that implied that she initially belonged there, 
vanishes: "The brown herd of horses? Where had it gone? Not once had she seen it here" (Skram, 1978: 71).

"[W]hen entrance is voluntary", Goffman writes, "the recruit has already partially withdrawn from his homeworld; what is cleanly severed by the institution is something that had already started to decay" (Goffman, 2009: 14). A crucial detail in Kant's case, is that she enters the institution in question voluntarily albeit reluctantly. Therefore, there is no clear-cut divide to be found between a normal, domestic sphere where she is well adjusted and content and a radically different animalistic sphere to which she does not belong. The herd of horses that appears when Kant is at home and ceases to exist when she is hospitalized emphasizes her as a border case. Despite the initial need to separate herself from the 'crazier' patients, Goffman might describe this as "being contaminated by contact with undesirable fellow inmates" (Goffman, 2009: 29), Kant gradually starts to think of herself as an ally to her fellow patients. At the same time, her praise of the delirists can be read as gratitude of her placement above them in the institution's hierarchy and structure. Either way, Kant exposes and evades the institution's established categories.

In a confrontation with the professor, Kant asks rhetorically if he will not trade beds with her for a night so as to see what it is like being kept in a cell and as he replies she has the following reflection: "No-o, he said, and it sounded like a horse's whinnying" (Skram, 1978: 69); this seems critical in our context. Shortly after, Kant provokes the professor into losing his temper by constantly criticizing his methods. With a stroke of involuntary comedy, the professor screams that Kant is unable to control herself and that he had thought of moving her but that she can now stay where she is:

\begin{abstract}
"Hieronimus' colourless face had turned grey as chalk. He lifted himself up to his toes and put his heels against the floor. - What You need most of all is to learn self-restraint! Your illness is that you cannot restrain yourself. I had planned on moving You - he smacked his one hand's tiny, plebeianly formed fingers against the other's inner palm and almost screamed: - But now You can stay where You are! and off he went out of the cell" (Skram, 1978: 70).
\end{abstract}

First this too, is addressed by Goffman, who claims: "To defend his own professional role and the institution that hires him, the psychiatrist is under pressure to respond by treating [...] outpourings not as [...] usable statements of information but rather as signs of the illness itself" (Goffman, 2009: 367). Second, as Unni Langås has shown in her reading of Skram's novel, this sequence reveals that the professor possesses 
the same traits that he accuses his patient of, namely a lack of self-restraint. His criteria for 'madness', then, is not something that separates the two as doctor and patient but something that connects them (Langås, 2004: 219). The connotation of a horse's neighing in the distance right before the professor's lack of self-control becomes visible to us, works as a possible elaboration of Langås' point.

On the one hand, the association to a horse places the professor in the same sphere as his patients, the animal-like sphere, and this can be seen as a foreshadowing of the imminent revealing of him as equally irrational, subjective and temperamental as Kant. On the other hand, the animal in question is not to be treated as a coincidence: Horses are not mentioned as one of the animals the uncontrolled patients remind Kant of as they scream in the night (they are affiliated with wild animals and dogs, owls, oxen and roosters). The neighing connotates the herd of horses that Kant hallucinates at the beginning of the novel that disappears as she becomes integrated into the institution's social structure. This detail suggests, that Kant and the professor both reveal an affiliation to an animal-like sphere, although on a somewhat higher level than the patients that have no other mode of protest or self-expression than persistent nocturnal screams. And still, there is a dignity affiliated with Kant's hallucinated horses that disappears with the professor's distant neighing. Either way, as a reminder of Felman's previously mentioned insights on madness as the inside of a culture when becoming commonplace, we can say that Kant in these sequences exposes the categories of the rigid asylum structure as arbitrary.

\section{Partial animality, total institution}

Goffman describes the total institution as a "social hybrid", part community and part formal organization (Goffman, 2009: 12). With this in mind, we can note that Else Kant's gradual alliance with the secluded sphere does not represent an exclusion from social life as one might have expected when reading Professor Hieronimus in light of Homo sacer. In her transition to and acceptance of her affiliation with the 'animal sphere' of the asylum she gains a community and starts communicating better with both her fellow patients, the nurses, and even a doctor. She is also able to care for other patients, urging them to obey the nurses' orders and restrain themselves. Kant's gradual internalization in the structure of the mental institution is a complex matter and it is not something inherently good or bad. That depends on how we view this sort of compliance, brought forward by a hierarchal 
demand for acquiescence, which the novel was, understandably, read as a critique of. Skram's novel, thus, reminds us of Kant as a border case and the patient narrative as a fundamentally complex one.

In his influential work The wounded storyteller (1995), Arthur W. Frank states (with a reference to Howard Waitzkin):

"The ideological work of medicine is to get the patient to accept [a] diagnostic identity as appropriate and moral. When the patient accepts this identity, he aligns himself as subordinate in a power relation" (Frank, 1995: 66).

This is yet another example of an interdisciplinary study affiliated with the field of literature and medicine addressing a phenomenon already formulated in Skram's novel and it is this effective social organization that enables a parallel between the hospital in Professor Hieronimus and Goffman's description of the total institution. The question of patient subordination is, however, slightly more complicated in Skram's case; as the novel invites us to view it in a meta-perspective. When this is considered, the novel in itself serves as proof that the professor is indeed (as promised by his patient at the end of the first novel) held accountable for his (mis) treatment of her. In this perspective, the internalization found in Professor Hieronimus can be understood as a gradual build-up to a more profound protest of the structures at play in regards to Else Kant's hospitalization.

Like Agamben's werewolf, Kant belongs neither fully to the sphere of normality, as is made evident when she fails to get her husband to see the herd of horses allegedly passing through their home, nor to the sphere of animality. As a patient, she inhabits a threshold existence. This is how Skram's protagonist, who is in a way on the outside of society and refused access to it, still remains deeply connected to the powers that have placed her there. Thus, Professor Hieronimus serves as a good starting point for a longer exploration about the significance of isolation in patient stories, all the while reminding us that no institution is so closed off from society that it does not bear the potential to communicate something about said society by way of examining what it isolates, condemns and excludes. On the contrary: The more closed off an institution is, the more reason to dissect its structures. This is what Skram enables in her novel. In making her protagonist a subversive observer of the medical institution, she creates a literary character deserving of the theoretical developments that were still far ahead at the time of her creation. 


\section{Notes}

1 For details on how the novel complies with biographical circumstances, see for example Engelstad (1996), Hamm (2000), Aaslestad (2009) or Bondevik (2010).

2 Goffman establishes five rough groupings of total institutions: Institutions that are "established to care for persons felt to be both incapable and harmless, [...] places established to care for persons felt to be both incapable of looking after themselves and a threat to the community [...]. A third type of total institution is organized to protect the community against what are felt to be intentional dangers to it [...]. Fourth, there are institutions purportedly established the better to pursue some worklike task and justifying themselves only on these instrumental grounds [...]. Finally, there are those establishments designed as retreats from the world even while often serving also as training stations for the religious" (Goffman, 2009: 4-5).

3 Translations are mine.

\section{References}

Aaslestad, Petter (2009). »Amalie Skrams asylromaner revisited«. Edda 1/09, vol. 96. (2007). Pasienten som tekst. Fortellerrollen i psykiatriske journaler Gaustad 1890-1990. Oslo: Universitetsforlaget.

Agamben, Giorgio (1995). Homo sacer. Sovereign power and bare life. California: Stanford University Press.

Bernhardsson, Katarina (2010). Litterära besvär. Skildringar av sjukdom i samtida svensk prosa. Stockholm: Ellerströms.

Bondevik Hilde (2010). »Who's afraid of Amalie Skram? Hysteria and Rebellion in Amalie Skram's novels of Mental Hospitals« in Stene-Johansen, Knut and Frederik Tygstrup (ed.) Illness in Context. New York: Rodopi. https://doi.org/10.1155/2012/490647

Bondevik, Hilde and Knut Stene-Johansen (2011). Sykdom som litteratur. 13 utvalgte diagnoser. Oslo: Unipub.

Dahlerup, Pil (1975). »Den kvindelige naturalist«. Vinduet 2/75, vol. 29.

Ditlevsen, Tove (1968). Ansigterne. København: Steen Hasselbalch.

Engelstad, Irene (1992). Sammenbrudd og gjennombrudd. Amalie Skrams romaner om ekteskap og sinnssykdom. Oslo: Pax forlag.

Engelstad, Irene (1996). »Er det mulig å male livsangstens symbol? Amalie Skrams Professor Hieronimus og På St. Jørgen som kunstnerromaner« in Aasen, Elisabeth (ed.): Amalie. Silkestrilen sin datter. Bergen: Amalie Skram selskapet.

Felman, Shoshana (2003 [1985]). Writing and madness (Literature. Philosophy. Psychoanalysis). California: Stanford University Press.

Foucault, Michel (2008 [1961]). Galskapens historie i opplysningens tidsalder. Polen: Gyldendal Akademisk.

Frank, Arthur (2013 [1995]). The wounded storyteller. Body, illness and ethics. Chicago and London: The University of Chicago Press.

Goffman, Erving (2009[1961]). Asylums. Essays on the social situation of mental patients and other inmates. London: Transaction Publishers. 
Hamm, Christine (2000). »Sannhet og sinnssykdom: En lesning av Amalie Skrams romaner Professor Hieronimus og Paa St. Jørgen« in Bøe, Yngvild (ed.): Årbok 2000. 7. årgang. Bergen: Amalie Skram selskapet.

Hawkins, Anne Hunsaker (1999). Reconstructing illness. Studies in pathography. Indiana: Purdue University Press.

Johansen, Helga 1900). Hinsides. En psykologisk Redegjørelse. København: Lehmann \& Stages Forlag.

Kragh, Jesper Vaczy (2008). Psykiatriens historie i Danmark, København: Hans Reitzels forlag. Langås, Unni (2004). Kroppens betydning i norsk litteratur 1800-1900. Bergen: Fagbokforlaget. Nielsen, Jens-Emil (2018). Mennesker på sindssygehospital. En krønike om Sct. Hans, Risskoc, Oringe, Viborg, Middelfart, Nykøbing S., Vedsted og Augustenborg. København: Bogforlaget HER\&NU.

Skram, Amalie (1978 [1895]). Professor Hieronimus. Oslo: Pax forlag.

Sontag, Susan (1991 [1978]). Illness as Metaphor \& AIDS and its Metaphors. England: Penguin books.

Woolf, Virginia (2002). On being ill. Ashfield, Massachusetts: Paris Press. 